\title{
咀嚼粉砕の対数法則について On the Law of Logarithmic Oder of Mastication
}

(昭和 36 年 4 月 27 日 受理)

$\begin{array}{cccc}\text { 三丨 代 幸 彦 } & \text { 中 山. 義 之 } \\ \text { (Yukihiko Mishiro) } & \text { (Yoshiyuki Nakayama) }\end{array}$

The authors have found that equal fractions of the number of raw rice particles are shattered by each successive stroke of an equal count of mastication. The mathematical representation of this statement is

$$
\text { or } \begin{aligned}
& \lambda=N_{0} \cdot 10^{-k t} \\
& \log \left(\frac{N}{N_{0}^{-}} \times 100\right)=2-k t
\end{aligned}
$$

where $N_{0}$ is the number of raw rice particle, $N$ is its number after the masticatory stroke $(t)$, and the constant $k$ is the mastication coefficient (masticatory index).

生体における栄養学的生化学的問題の最初の課程は咀 である。その生理化学的意義に関しては不明の点もあ るが，最も重要な機能は食物を粉砕して消化管内の通過 を容易にし，また，消化群素の作用面積を增大させるこ とであると考えられている。したがって，咀噮が可成複 䊒な因子に支眍されているとしても第1近似として粉研 能を取上げることは当をえた方法と考えられる。もちろ んこれによって咀徱の状態を全面的に表現できるわけで はないか，現在の段階では咀礵研究の本筋と目されてい る。

咀嘌能を粉碎能に㯰きかえて考察するとして，粉砕の 経過は如何なる規則性に基ついて進行しているであろう か。古く Manly (1950-1 $)^{112)}$ は対数確率法則が成立す ることを，石原 $(1955-6)^{3 / 4)}$ は一定の粒度分布式が成立 ナること,ならびに咀獣回数と節上\%との関係汁指数函 数であらわされることを報告している。ともに優れた業 港であり，いずれもいわゆる穊分法による粒度重最分析 加導かれている。石原によると健全歯列による咀嚼は 任意の単一篩径を用いるだけで全般の粒度分布を知りう るが, 病的菌列においては単一節による測定は全般をあ らわさないという。しかし，平均節径 $2.18 \mathrm{~mm}$ の 10 メッ シュ穊は各種口腔状愁による咀嶰効果の差を検出するに は最も敏感であり，単一節径のみによって測定するには このよらな大笠径のものを用いるがよいと述へている。

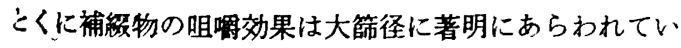
るといら。

そこで著者らはより単純な考察に基ういて，咀謝を粉 醉をらける粒子数で取扱ってみた。これは大笠径単一節
分法に類似するものと考える。

いま $N$ 個の粒子があって， $d t$ 回咀敝することによっ て $N \cdot d N$ になったとする。粒子の減少する割合が粒子 数 $N$ に比例すると仮定すれば,

$$
-\frac{d N}{d t}=\alpha N
$$

である。ここに $\alpha$ は比例常数である。(1) 式を積分し, $t=0$ のとき $N=N_{0}$ の条件を入れると，

$$
N=N_{0} e^{-d} t
$$

常用対数に直して,

$$
N=N_{0} \cdot 10^{-k l}
$$

すなわち，

$$
k=\frac{\log N_{0}-\log N}{t}
$$

また，N/No の百分率 $(a)$ をとった場合は，

$$
a=100 \cdot 10^{-k t}
$$

故に,

$$
\log a=2-k t \text {. }
$$

が成立するはずである。ただし，咀䊀においてては一定咀 喵回数以上では未粉砕の粒子は 0 となり, 当然これらの 諸式は成立しなくなる。

このことを予为許容した上で，本報告は以上の対数法 則がどの程度あてはまるかを実駼的に追究したものであ る。一定数の生米を咀嘎した後にビーカーに吐出し，粘 稠な喠液を除くために 2 3 回水洗し，全く粉砕をうけ ない米粒を数える極めて簡単な方法である。箁分法にお けるような唾液による粒子の膨潤や䩐燥程度を考虑する 必要がなく，極めて手柽迅速に行なうことができる。 


\section{実 験 結 果}

\section{1) 末粉砕\%の测定部差}

計算の便索考えて 100 粒の生米 $\left(N_{0}=100\right)$ を慣用歯列

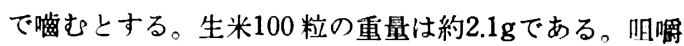
回数を 10 回に規定して同じ実験を 10 回行い，それぞれ の場合に全然粉砕をうけなかった米粒の数を求める。こ

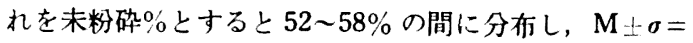
$55 \pm 2.2$ となり，変異係数は $4.0 \%$ である。

第 1 表種々の咀啊回数 $(t)$ に扩ける 末粉矽\%の变異係数

\begin{tabular}{ccccc}
\hline \multicolumn{1}{c}{$t$} & 10 & 20 & 30 & 40 \\
洌 & ${ }^{\%}$ & $\%$ & $\%$ & $\%$ \\
2 & $3.3^{\%}$ & $4.0^{\%}$ & 5.5 & 8.5 \\
3 & 1.1 & 4.5 & 12.5 & 23.6 \\
4 & 3.8 & 5.3 & 12.3 & 18.2 \\
平 均 & 2.6 & 5.6 & 12.4 & 16.1 \\
\hline
\end{tabular}

次に4名について10４0回咀嚼したときの未粉砕\%の 変異倸数主第 1 表にまとめた。一般に咀哷回数がます上 変異倸数は大上なる。とくに末粉砕\%が30以下の領域で は10\%。吉こえるようになる。表中の縦線の向って右側が これに相当する、未粉砕\%が50以上の領域では変異釈数 法 3ー4 \%あるいはそれ以下である。

3) 対数法則適台性の検討

寸でに石原は篩上\% (対数) と咀嶰回数との間には直 線関係のあることを指摘している。3) こ㞦を末粉砕\% (対数)と咀䊩回数におきかえてみるわけである。

对数法則が成立するか否かを検㣙するには一般に $3 つ$ の方法がある。前述の (1) 式を㨁ちに利用して $\frac{\Delta N}{\Delta t}$ と $N$ との関係をしらバる方法は微分法とよばれ，これによっ て一定勾配の直線がえられればよい。また, 後述の半減 第 1 図直楾的回踻 (対数法則)

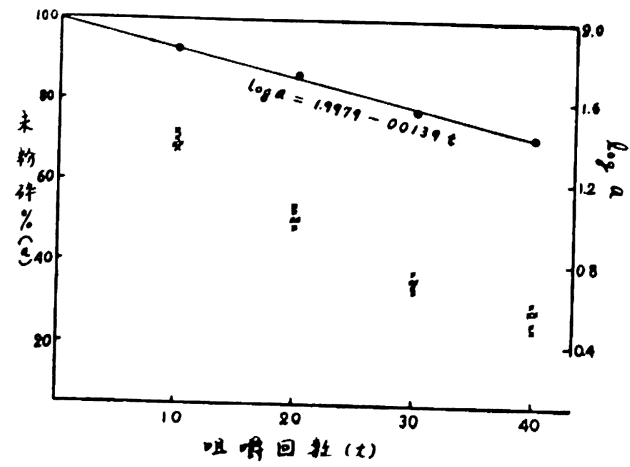

期法によっても検即することができる。しかし最もよく 用いられるのは椟分法であり，(3) あるいは (4) 式を利用 して咀楀回数 $(t)$ に対して末粉䂶\%の対数 $(\log a)$ を图 示し直線がえられればよい。

$10 \sim 40$ 回咀蹗した場合の $a$ を図示したのが第 1 図で ある。各群それぞれ観測数は 5 である。緃軸の值 (a\%) の各平均值を求め, その対数値をとったのが図の黒点で ある。これらは一直線上に配列しているように思われる。 最小二乗法によって偏差の最も少ない直線を求めるに,

$$
\log a=1.9979-0.0139 t
$$

上なる。上式から回帰係数 $(k)$ は 0.0139 である

この直線的回帰の分散分析の結果を第 2 表にしめす。 分散比は 1593 で非常に大きく，危険率は $0.1 \%$ 以下で あり，直線関係をよく満足している。

第 2 表 回帰の分敏分析

\begin{tabular}{|c|c|c|c|c|c|}
\hline 因 & 自由度 & 平均和 & 分 散 & 分散比 & $P$ \\
\hline 㨁線的回帰 & 1 & 0.97176 & 0.97176 & 1593.04 & $<0.001$ \\
\hline $\begin{array}{l}\text { 回㷌からの } \\
\text { 偏 }\end{array}$ & 3 & 0.00525 & 0.00175 & 2.87 & $\therefore$ \\
\hline $\begin{array}{l}\text { 任意抽出法 } \\
\text { (骂 差) }\end{array}$ & 20 & 0.01220 & 0.00061 & -1 & 一 \\
\hline
\end{tabular}

さて，回帰係数は最小二乗法で求めるのが最も正確で あるが，簢単には算術平均として求めればよい。10 40 回咀緭した上きの各観測値の $k$ を (4) 式を変形した

$$
k=\frac{2-\log a}{t}
$$

から算出すると $\mathrm{M} \pm \sigma=0.0142 \pm 0.0012$ となり，変異倸

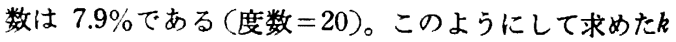
値はく51式のそれに非常に近く，咀㛵粉研の経過にはこの 場合は,

$$
\log a=2-0.014 t
$$

の関係があるということができる。

4 名について上と同様にして $k$ の変異係数ならびに標 淮呺差を求めると第 3 表の成績になる。変異係数は平均

\begin{tabular}{|c|c|c|c|}
\hline 例 & 例 数 & $\mathbf{M}_{ \pm} \boldsymbol{\sigma}$ & 变異係数 \\
\hline 1 & 20 & $0.0142 \pm 0.0012$ & $7.9^{\%}$ \\
\hline 2 & 16 & $0.0206 \pm 0.0030$ & 14.0 \\
\hline 3 & 16 & $0.0244 \pm 0.0020$ & 8.3 \\
\hline 4 & 16 & $0.0261 \pm 0.0025$ & 9.5 \\
\hline 平 均 & & & 10.1 \\
\hline
\end{tabular}
して約 $10 \%$ であ。

第3表 $K$ の变異保数 


\section{3) 回㷌係数 $k$ の意味}

(3)あるいは(6)式で与えられる $k$ は咀唵回数に $t$ は無関 系な值としてえられるから，初期粒子数 $N_{0}$ を一定とすれ ばこれによって各人の粉碎能を比較できる。第 2 図は 4 名のa-t 関係を片対数表にしめしたものである。各人の $k$ を直線上に記载してある。 $k$ の高い程粉砕能がよいので ある。この意味から回㷌係数 $k$ を咀嗘の場合は咀䊩倸数 とよふことができる。また当然 $k$ は半減期法によって求 カることができる。(3)式において $N=\frac{1}{2} N_{0}$ になる咀啋 回数を $t_{1} 2$ とすれば

$$
k=\frac{\log 2}{t_{1.2}} \text { あるいは } k t_{1 \ell^{p}}=\log 2
$$

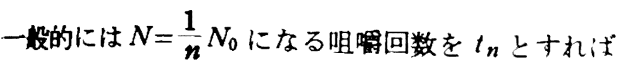

$$
k t_{n}=\log n
$$

であるっこれは $(6)$ 式と全く同じ内容である，後述のよう に $t_{n}$ は $N_{0}$ に比例し， $k$ は $N_{0}$ に逆比例するから, $k t_{n}$ は $N_{0}$ に無関保に寸べての人に共通の一定値になるわけだ ある。

さて， $k$ は直観によってこれを理解するのに困難であ る。初期粒子数 $N_{0}$ 老一定として，一定の未粉砕\%に達 するには何回啮まねばならないかで表現した方が理解し 易い。第 2 図において，例えば30\%ライン圭上れば各人 それぞれ 10，21.3，26.5，34.5 回咀撔する必要がある。逆 にこの回数に各人の $k$ 值をかけたものは7式からもわか るよ5に $\log \frac{100}{30}$ すなわち $2-\log 30$ テあり，10回を規 準にとれば他の人はそれぞれその 2.1，2.7，3.5 倍余計に 啮まねばならないことがわかる。勿論何\%ラインを上っ てもこの倍数值は同一になる理である。また，7式から の当然の帰結として各人の $1 k$ の比もこれと全く同じに ならなけれ六ならない。実測値でこれを計算すると 0.052 をそれぞれ $0.024,0.020,0.015$ で割って 2.1，2.6, 3.5 上 なる。ただしここような各人の比を算出するには各人

第2四片対数グラフによる各人の $a-t$ 直線

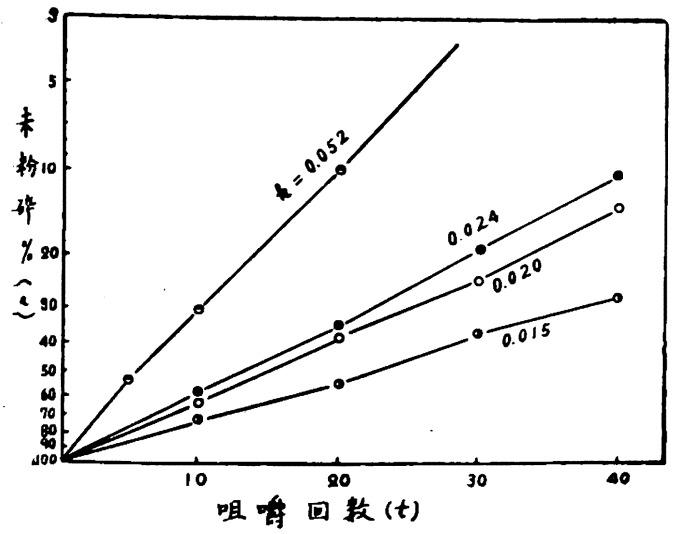

の $N_{0}$ は同一でなければならない。

粉砕能をみるには咀哷回数だけでなく粒子数にも無関 係な值であることが望ましい，因みに $N_{0}$ 上 $k$ の関係を片 対数表によって図示寸ると第 3 図がえら机る。 $N_{0}$ が 25, $50 ， 100 ， 150$ 粒の上きk㳉それぞれ0.062，0.033，0.015, 0.011である。才なわち，25１50粒の箱囲内では $k N_{0}$ は

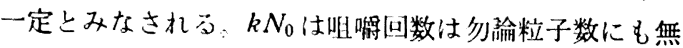
関倸な個人周有の值であるから，これ老勗罟恒数とよぶ こレにする。

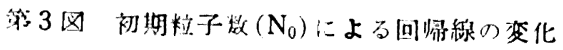

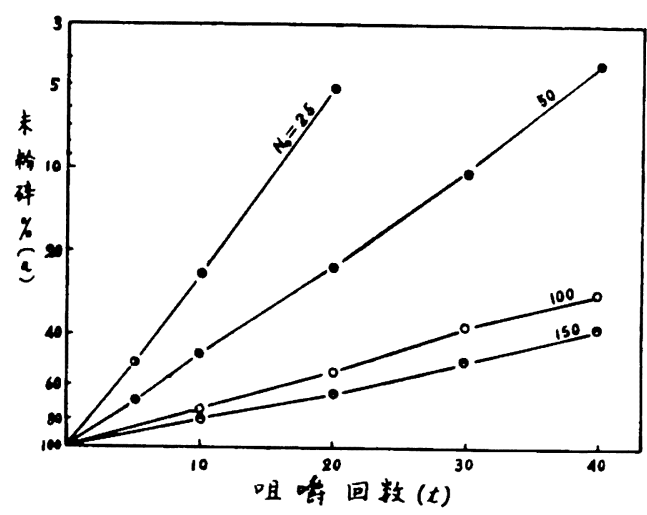

考祭

咀翾によ一て生米の数が減少する経過はこく狭い一定 籁用内で:対数確率法則に従っているようにもみえる が，広い筑囲在とるとむしろ対数法則により良く支配さ れている、十なれち，末粉砕の粒子数仕ある定ま一た咀 嚼回数に対してある定まった䑡合に減少し，

$$
N=N_{0} \cdot 10^{-k t}
$$

なる2地が成访する。こニには $N_{0}$ 初期粒子数， $N$ は $t$ 回 咀嗨したときの全然粉砕在うけていない粒子の数であ る。これ咀薭の粉砕公式上よじ， $a=\frac{N}{N_{0}} \times 100$ を末汾 砕\%， $\frac{N_{0}-N}{N_{0}} \times 100$ 在粉确\%， $\log N_{0} N=k t$ を粉砕

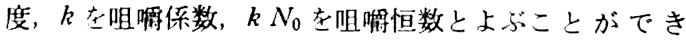
る。しかして $k$ は $t$ に無関係な個人の值上してえられ， $k N_{0}$ : $t$ 上 $N_{0}$ に無関保な個人阔有の值上してえられ る。また，一定の未粉砕。(あるいは粉砕％）に执いて は $k t$ は各人に共通の值になる。しかし教数法則もけっ して粉砕に本質的なものではなく，一定回数以上に咀嗳

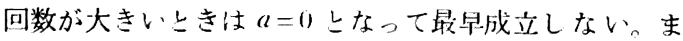
た，対数法則に従うと考えて求めた $k$ 洨異係数約 $10 \%$ (標準誤差の平均值に対する百分率は $2.6 \%$ ) であり，こ れ以上の測定精度は無理である。メランジュールによス 血球計算における精度と同程度と考えられる。 
結 論

1）勗嘚によって全然粉砕をうけない生米の粒子数が 減少する過程は対数法則に支配されている。

2) 未粉砕。の变異係数は咀啲回数が增すと大きくな ప。

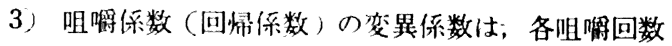
のものを一括計算して約10\%である。平均值に対する標 淮誤差の百分率㳉 $3 \%$ 以内である。

4) 咀嗳倸数 $k$ は咀嚼回数に無関倸な個有の值として え礼る。
5) 咀嚼恒数 $k N_{0}$ は咀噃回数, 初期粒子数化無関保 な個人に個有の値としてえられる。ただし，適用箅囲は 実験的に $N_{0}=25 \sim 150$ である。

\section{文南}

1) Manly, R.S. \& Vinton, P.: J.D. Res,, 30, 314 (1951)

2) Manly, R.S. \& Braley, L.C.: J.D. Res., 29, 448 (1950)

3）矿原寿郎：口病誌, 22, 207 (1955)

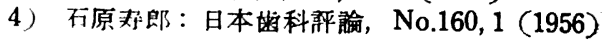

(日本橉科大学生化学数空)

\section{蛋白欠乏児のクレアチニン代謝}

カシオルコールで入院した9人の6〜9才の子供は, 入院時クレアチニンの排泄量が極めて少なかったが，治 療開始後第 1 週に, 激増した。その増加度は, 筋肉量の 增加程度以上であった，尿中へのクレアチニン排泄量の 増加と反比例して, 血清クレアチニン量は減少した。そ

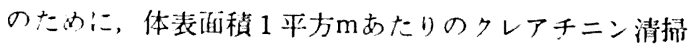
率㳉，最初急減し，第1週の終りまでに急增した。

$2 \sim 6$ 力月治擔䘮続け一，臨床後には全く回復した後
も，血清クレアチニン量は $0.46 \sim 0.57 \mathrm{mg} / \mathrm{dl}$ で，16人の 栄養可良な対象児童が $0.78 \mathrm{mg} / \mathrm{dl}$ であるのにくらへて。 著しく低い価を示した。

Serum and Urinary Creatinine in Children with Severe Protein Malnutrition by G. ARROYAVE et al.

The Amer. Jour. of Clin. Nutr. 9, 176 (1961)

(小 池)

\section{人体組武のカゥ含}

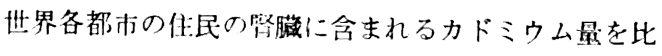
較してみると，日本人の值汁最も多く，アフリカ人は最 も少ない。後者の婜中にはカドミウムを証明できない。 新生悓の体内にはカドミウム在証明できない。従来カド ミウムは㐩成分上考六られていたが，その点についても 問題がある。卧中カドミウム量は60才までは年令ととも に增加し，それから減少する。アメリカ人の婜中含有最 は，生澸器中に $40 \mathrm{mg} / \mathrm{kg}$ で，日本人のは，その約 2 倍 である。食物中には，海竡物之穀物中に多い。1日の提
取量は，4－60 $\mu \mathrm{g} /$ 日である。日本人は，米をたくさん 食べるので，カドミウム翼取量が多い。

カドミウムが体内生理作用に不可欠のものかどうか, 現在不明で，今のところ，組織の活性度に対して，抑制 的に㗢くことが知られているだけである。

Abnormal Trace Metals in Man: Cadmium by Henry A. Schroeder, et. al., Journ. of Chro. Dis. 14 (2), 236 258 (1961)

(小 池) 